\title{
Assessing trophic state of surface waters of Służewiecki Stream (Warsaw)
}

\author{
Małgorzata Wojtkowska' ${ }^{1}$ (D) Damian Bojanowski ${ }^{2}$
}

Received: 22 December 2020 / Accepted: 7 June 2021 / Published online: 22 June 2021

(c) The Author(s) 2021

\begin{abstract}
Phosphorus $(\mathrm{P})$ is one of the key nutrient compounds for phytoplankton grow. In the conducted work, eutrophication indexes were used for the assessment of eutrophication level of water course (Służewiecki Stream) and the waters of nearby lakes (Bottom Berensewicz's Pond, Wyścigi Pond, Wilanowskie Lake). Calculating eutrophication indexes were based on the most important indicators which is crucial for eutrophication process: total phosphorus (TP), total nitrogen (TN), chlorophyll a $(\mathrm{Chl}(a))$ and water transparency. The research revealed that the concentration of phosphorus and nitrogen in the analysed waters determined intensity of trophic processes. The average concentration of both indicators was high: $0.81 \mathrm{mg} / \mathrm{l} \mathrm{TP}$ and $6.8 \mathrm{mg} / \mathrm{l} \mathrm{TN}$. During this research, two approaches were used: trophic state index (TSI) and trophic level index (TLI). TSI (TP) in Służewiecki Stream were, respectively: 83 and 6.5 whilst for standing waters (lake and ponds) 87 and 6.6. Both indexes indicated high trophic state and confirmed that eutrophication is a serious endangerment for analysed surface waters. Calculated indexes used in the assessment were sufficient and effective for sustainable water protection and management of water quality in Służewiecki Stream and in standing waters.
\end{abstract}

Keywords Eutrophication $\cdot$ Nutrients $\cdot$ Water quality $\cdot$ Warsaw (Poland)

\section{Introduction}

The excess of nutrients (phosphorus and nitrogen) introduced to reservoirs and water courses in the result of anthropogenic activities combined with other factors like hydrological modifications, changes of temperature or insolation may cause eutrophication which is enlarged accumulation of organic matter from water plants and algae overgrowth. Those blooms may be unaesthetic and in some cases produce toxins and harmful odours. It may lead to occurrence of low level of dissolved oxygen which may result in a reduction of biodiversity of fish and other aquatic species. Determination

Małgorzata Wojtkowska

malgorzata.wojtkowska@pw.edu.pl

Damian Bojanowski

bojanows@agh.edu.pl

1 Faculty of Building Services, Hydro and Environmental Engineering, Warsaw University of Technology, 00-653 Warszawa, Poland

2 Faculty of Geology, Geophysics and Environment Protection, AGH University of Science and Technology in Kraków, 30-059 Kraków, Poland of nutrient loads which may be assimilated by the water body may be difficult, because in the opposition of other specific substances, certain amount of nutrients is essential to maintain aquatic life. According to this, there is a need of controlling excessive inflow of nutrients and other parameters which may increase eutrophication. It is important to track the source of nutrients. Inland waters should be analysed to determine if there is an inflow of anthropogenic nutrient loads causing eutrophication, especially to examine possibility of algae bloom, decreases of dissolved oxygen and $\mathrm{pH}$.

While the symptoms of eutrophication differ depending on typology of water body, the concept of developing tools to diagnose eutrophication and identifying nutrients is similar for every type of surface water body. Nutrients like phosphorus and nitrogen occur naturally in surface waters and are basic compounds having an impact on amount of biomass in water bodies. In natural conditions, their circulation is regulated in a cycle and their total amount in ecosystems does not change significantly. Intensification of human activity, especially wastewater management and agriculture, has significant impact on circulation cycle of nutrients in water environment (Wojtkowska and Dmochowski 2009). Higher 
nutrient loads in water ecosystems, which means increase in substrates in processes of creating biomass, lead to faster dynamics of these processes which is observed as higher productivity (algae blooms). This results in the existence of an anaerobic zone at the bottom of the reservoir and increase in putrefaction processes. For eutrophication, typical species are cyanobacteria, phytoplankton algae, green algae and diatoms (Neverova-Dziopak 2007).

Anthropogenic eutrophication causes many disadvantageous consequences for users of aquatic ecosystems, such as increase in costs of water purification, sanitary threat and transformation of lakes into swamps. Indicators of eutrophication are used to assess the risk of eutrophication of surface waters. The methods of their calculation are various, and their basics are based on assessing the factors which may be responsible for eutrophication or may be used for assessing its effects. They are often customized for particular area or even for single reservoirs.

Assessment the level of eutrophication is based mainly on determination water body productivity (Neverova-Dziopak 2007). There are three different types of water bodies according to their intensity of production processes: oligotrophic, mesotrophic and eutrophic. The methods of the assessment of trophic state may be based on particular parameters, which influence biological processes, relevant in the context of eutrophication, such as nutrients, concentration of chlorophyll a, but also temperature, insolation and dissolved oxygen, certain species of algae and fish (Neverova-Dziopak 2007). Besides of assessment of each of those parameters, basing on available limit values specified in the literature or legal standards, there are also methods based on particular parameters aggregated as indexes which includes certain relations between those parameters. To evaluate trophic state of surface waters, several parameters are used. The most important of them are levels of phosphorus, nitrate, chlorophyll a, dissolved oxygen and water transparency (ElSerehy et al. 2018). In fact, the assessment of water quality is very important, when it comes to balance the ecological and social-economic interests. There were many approaches to assess quality of rivers and lakes worldwide. In 1965 in the USA, Horton (1965) developed water quality index (WQI) which was widely used and accepted in Europe, Africa and Asia. Carlson (1977) developed numerical classification of lake trophic state-trophic state index (TSI), in Burns et al. (2005) modified Carlson's TSI into trophic level index (TLI).

To simultaneously assess trophic state, chemical and biological conditions of reservoirs, there is a need to find an index which includes those factors and allows to widely assess ongoing processes and their dynamics in waters. That index may be analysis of stable isotopes of elements which naturally occurs in water environment, mostly nitrogen and carbon. Comparison of amount of certain isotopes of particular element may indicate the intensity of the processes which depends on metabolism of water organisms (especially production) (Bartoszek et al. 2018). The $\delta^{13} \mathrm{C}$ index shows the difference between ratio of carbon isotopes ${ }^{13} \mathrm{C}$ and ${ }^{12} \mathrm{C}$ in analysed example and ratio of those isotopes in reference sample which may be mineral oil with known (Bartoszek et al. 2018). This index is presented as per mille of difference between those ratios. This ratio is correlated with amount of nutrients in water and with other trophic indexes such as TSI, so it is possibility of usage of this index as a new index of trophic state in water quality analysis (Gu et al. 2011; Lehmann et al. 2004; Bartoszek et al. 2018; El-Serehy et al. 2018).

The aim of study was to do the research which may evaluate the trophic state of stream and reservoirs. The tests were conducted for surface waters localised in the area of agglomeration of city of Warsaw: Służewiecki Stream, Wilanowskie Lake, Bottom Berensewicz's Pond, Wyścigi Pond (Fig. 1). The assessment of water quality was carried basing of biological and physicochemical analysis.

\section{Characteristics of analysed objects}

Służewiecki Stream is not designed as single water body in the meaning of Water Framework Directive, and it is not included in National Monitoring Programme (WIOŚ 2017). It is included in water body "Wilanówka" (PLRW20002625929). Stream is a watercourse which is located all along in the area of City of Warsaw. The sources are located near the Chopin Airport (Okęcie district) and it mouths to Wilanowskie Lake within the sites of King John the third Park Museum. The length of stream is about $8 \mathrm{~km}$. Around the stream, there are reservoirs fed with waters of stream:

- Two Ponds (Berensewicz's Upper and Bottom)—outside the riverbed

- Wyścigi Pond-directly in the riverbed

- Ponds at the area of Dolinka Służewiecka park-outside the riverbed (PRNG 2018).

According to Corine Land Cover 2018 land use of the streams's catchment area is mostly (53\%) discontinuous urban, 24\% -industrial, commercial or transport and $24 \%$-other. $7 \%$ of catchment is managed as agricultural.

To obtain the aim of the study nine monitoring points were designated. All samples were taken between May and October 2018. Detailed information of each point is presented in Table 1. The location of monitoring point and basic information about studied area is presented in Fig. 1 . 

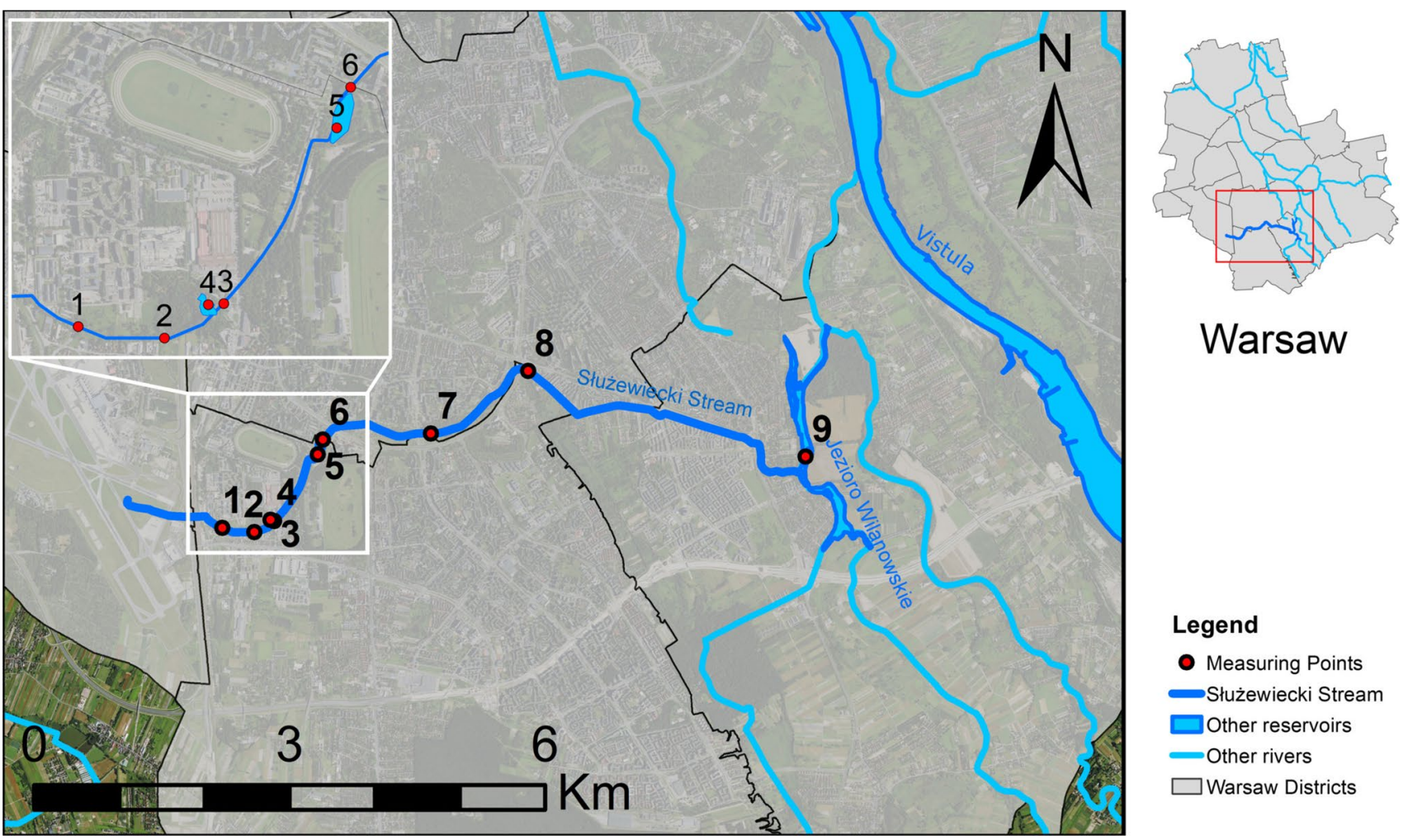

Warsaw

Fig. 1 Location of research area and measuring points

Table 1 Details of measuring points

\begin{tabular}{llll}
\hline ID & Point type & Point name & Annotations \\
\hline 1 & Stream & Kłobucka-Brigde & \\
2 & Stream & Wyczółki-Meadows & \\
3 & Stream & Wyczółki-Bridge & Below the pond \\
4 & Pond & Bottom Berensewicz's Pond & Outside the streambed \\
5 & Pond & Wyścigi Pond & \\
6 & Stream & Wyścigowa & Below the pond \\
7 & Stream & Dolinka Służewiecka Park-Bridge & \\
8 & Stream & Fosa-Bridge & Below the stream mouth \\
9 & Lake & Wilanowskie Lake &
\end{tabular}

\section{Methodology}

To conduct the research nine measuring points were designated in which six was localised at the riverbed of stream two ponds and Wilanowskie Lake. Water samples were taken four times: in May, July, August and October 2018. The physicochemical and biological parameters in collected samples were determined, which allowed to assess the level of eutrophication in stream, ponds and lake. In measurements included: total phosphorus (TP), orthophosphates, total nitrogen (TN), nitrates (V), nitrates (III), ammonia nitrogen, chlorophyll a and transparency
(Secchi's method with compatibility of EU standards). Prepared maps use data from polish River Basin Management Plans database (KZGW 2017) and national boundaries of administrative units (GUGiK 2021).

Each sample was taken once in amount of 21 . Chemical analysis has been made the same day as sampling. The following methods of chemical analysis were used: TN concentration: using Kjeldahl's method, $\mathrm{N}-\mathrm{NO}_{3}$ concentration: spectrophotometric nitrates determination using sodium salicylate (expressed as $\mathrm{N}$-form), $\mathrm{N}-\mathrm{NO}_{3}$ concentration: colorimetric nitrites detection using sulfanilic acid and $\alpha$-naphthylamine (expressed as $\mathrm{N}$-form), $\mathrm{N}-\mathrm{NH}_{3}$ concentration: Colorimetric ammonium detection using Nessler 
reagent (expressed as $\mathrm{N}$-form), TP concentration: spectrophotometric phosphorus determination using ammonium molybdate and tin (II) chloride after mineralization, $\mathrm{P}-\mathrm{PO}_{4}$ concentration: spectrophotometric phosphorus determination using ammonium molybdate and tin (II) chloride (expressed as P-form), $\mathrm{pH}$-electrometric method using an electrode, electrical conductivity using conductometer, general alkalinity - by titration against indicators (methyl orange and phenolphthalein); calcium concentration: by titration complexometric using sodium edetate, magnesium concentration: by titration complexometric method with the use of disodium edetate, chloride concentration: by Mohr's argentometric method, concentration of sulphates: by spectrophotometric method with the use of barium chloride, Secci's Depth: using Secchi disc, Chlorophyll a concentration in planktonic algae: using monochromatic spectrophotometric method with correction for phaeopigments a (PN-C-05560-01:1986), $\delta^{13} \mathrm{POC}$ content in suspension: after filtering a given volume of water through a glass fibre filter, dried at $50{ }^{\circ} \mathrm{C}$ and subjected to $\mathrm{HCl}$ vapours in a desiccator to remove carbonates. The filter with the sample was analysed with a DELTA Plus apparatus paired with a Flask 1112 apparatus for elemental analysis, TSI indicator: using Carlson's equitation (Carlson 1977), TLI indicator: using equitation given by Burns et al. (1999).

\section{Results and discussion}

To assess eutrophication level and obtain data for further TSI and TLI analysis, we performed chemical analysis of 16 parameters, including trophic-related and other physicochemical indicators. The analysis showed that both waters of Służewiecki Stream and analysed reservoirs showed high concentrations of nutrients. In waters from the stream, the amounts of TN were in the range of 2-14 mg N/l and TP between 0.04 and $2.24 \mathrm{mg} \mathrm{P} / \mathrm{l}$. The chlorophyll amount was in the range 1.1-62.7 $\mu \mathrm{g} / \mathrm{l}$. Comparison of those values with concentrations of orthophosphates and nitrogen forms indicates that nitrogen in analysed objects is mainly in organic form. Table 2 shows the detailed values of each measurement. Highest amounts of nutrients were observed in summer-autumn measurements and highest $\operatorname{Chl}(a)$ was observed in late-spring measurements which indicates impact of eutrophication and algae bloom on nutrient loads in stream and ponds. Służewiecki Stream flows through small agricultural (mostly allotments), however, its catchment is located mainly in urban area. According to conducted research, it is not recipient of any municipal wastewater (WIOŚ 2017, 2018) which means that main part of nutrient loads remains unidentified. It is unlikely that atmospheric deposition is responsible for such high concentration values, so illegal sewage or recharge from sediments may be the source of nutrient loads. Recharge from highly eutrophicated ponds located in area (both inside and outside streambed) may be source of nutrients in Służewiecki Stream. Values of $\delta^{13} \mathrm{POC}$ which might be good indicator of trophic state (Lehmann et al. 2004) were between $-34.1 \%$ and $-23.46 \%$, however, in this study, we did not find any correlation between $\delta^{13} \mathrm{POC}$ and other parameters.

Auxiliary parameters were analysed to provide indicative information about non-trophic-related state of stream and lake and ponds water. Performed analysis indicates high values of conductivity (for which good ecological valueGES for this type of water bodies are set at $795 \mu \mathrm{S} / \mathrm{cm}$ ), concentration of magnesium $(\mathrm{GES}=11.3 \mathrm{mg} / \mathrm{l})$ and concentration of chloride ion $(\mathrm{GES}=176 \mathrm{mg} / \mathrm{l})$. All values of these parameters in each point and measurement are presented in Table 3. High values of this parameters may be indicated by industrial pollution or rainwater discharges from urban area. The most significant industrial activity in catchment is National Airport. However, analysis of the loads from airport sewages was not part of this study so it is not possible to confirm airport influence on the quality of stream and transported loads.

\section{TSI Index in stream and reservoirs}

Basing on obtained concentrations of phosphorus chlorophyll a and Secchi's depth TSI was calculated. The most important index taking into account surface water trophic state TSI(Chl) based on chlorophyll a concentration as the determinant of biomass of algae was between 31-72 (Table 4) depending on measuring point and date of sampling. The lowest values were in summer (July) the highest - in autumn (September). For the stream average value of TSI (Chl) was 53, for Bottom Berensewicz's Pond-52, for Wyścigi Pond-50 and for Wilanowskie Lake 56. Those values of TSI (Chl) indicate trophic state as eutrophic, with the anoxic conditions and possibility of macrophytes growth.

Very important for trophic state evaluation is TSI (TP) index which was very high with values between $57-140$ with the average 83 in Służewiecki Stream, 87 in Bottom Berensewicz's Pond, 89 in Wyścigi Pond and 89 in Wilanowskie Lake (Table 4). All analysed objects where TSI (TP) is much higher than TSI (Chl) which may indicate that there are limitations for the algae growth like low nitrogen concentrations, low insolation or toxic substances. Obtained results indicated that availability of nitrogen may be bottleneck-the excesses of nitrogen was lower comparing to reference limit values than in case of total phosphates. TSI (SD) which is based on transparency (Secchi's depth) was between 50 and 66 (Table 4) which value is similar to values of index based on chlorophyll a. 
Table 2 Obtained results of trophic-related parameters

\begin{tabular}{|c|c|c|c|c|c|c|c|c|c|c|}
\hline$\overline{\text { Date }}$ & ID & $\begin{array}{l}\mathrm{TP} \\
\mathrm{mg} \mathrm{P} / 1\end{array}$ & $\begin{array}{l}\mathrm{P}-\mathrm{PO}_{4}{ }^{3-} \\
\mathrm{mg} \mathrm{P} / 1\end{array}$ & $\begin{array}{l}\mathrm{TN} \\
\mathrm{mg} \mathrm{N} / 1\end{array}$ & $\begin{array}{l}\mathrm{N}-\mathrm{NO}_{3} \\
\mathrm{mg} \mathrm{N} / 1\end{array}$ & $\begin{array}{l}\mathrm{N}-\mathrm{NO}_{2} \\
\mathrm{mg} \mathrm{N} / 1\end{array}$ & $\begin{array}{l}\mathrm{N}-\mathrm{NH}_{3} \\
\mathrm{mg} \mathrm{N} / 1\end{array}$ & $\begin{array}{l}\text { Secchi } \\
\mathrm{m}\end{array}$ & $\begin{array}{l}\text { Chl }(a) \\
\mu \mathrm{g} / 1\end{array}$ & $\begin{array}{l}\delta^{13} \mathrm{POC} \\
\% o\end{array}$ \\
\hline 05.2018 & 1 & 0.1 & 0.08 & 11.2 & 9 & 0.007 & 0.57 & 1 & 7.9 & -26.52 \\
\hline 05.2018 & 2 & 0.07 & 0.06 & 6 & 6 & 0.008 & 0.39 & - & - & -29.1 \\
\hline 05.2018 & 3 & 0.08 & 0.08 & 4 & 5 & 0.007 & 0.29 & 1.5 & 2 & -27.93 \\
\hline 05.2018 & 4 & 0.17 & 0.16 & 4 & 5 & 0.007 & 0.48 & 0.5 & 62.7 & -33.85 \\
\hline 05.2018 & 5 & 0.11 & 0.1 & 6 & 6 & 0 & 0.45 & 0.75 & 8.1 & -31.69 \\
\hline 05.2018 & 6 & 0.16 & 0.15 & 6 & 7 & 0.005 & 0.23 & 1 & 23.9 & -34.1 \\
\hline 05.2018 & 7 & 0.15 & 0.1 & 12 & 16 & 0 & 0.22 & 1 & 44 & -31.73 \\
\hline 05.2018 & 8 & 0.07 & 0.05 & 2 & 2 & 0 & 0.38 & 1 & 39.7 & -31.91 \\
\hline 05.2018 & 9 & 0.85 & 0.85 & 4 & 1 & 0.285 & 3.7 & 0.5 & 35.8 & -30.18 \\
\hline 07.2018 & 1 & 0.44 & 0.4 & 8.4 & 6 & 0.252 & 1.15 & 1 & 1.1 & -26.06 \\
\hline 07.2018 & 2 & 0.6 & 0.34 & 8.4 & 7 & 0.232 & 1.18 & - & 1.2 & -26.22 \\
\hline 07.2018 & 3 & 0.04 & 0.03 & 8.4 & 7 & 0.2 & 0.76 & 0.5 & 1.7 & -26.54 \\
\hline 07.2018 & 4 & 0.21 & 0.21 & 2.8 & 1 & 0 & 0.42 & 0.5 & 3.3 & - \\
\hline 07.2018 & 5 & 0.36 & 0.36 & 5.6 & 1 & 0 & 0.55 & 0.75 & 5.2 & -29.38 \\
\hline 07.2018 & 6 & 0.12 & 0.06 & 5.6 & 1 & 0.72 & 0.66 & 1 & - & -28.65 \\
\hline 07.2018 & 7 & 0.04 & 0.03 & 2.8 & 1 & 0.079 & 0.71 & 1 & 13.3 & -29 \\
\hline 07.2018 & 8 & 0.08 & 0.03 & 2.8 & 1 & 0 & 0.57 & 1 & 8 & -26.35 \\
\hline 07.2018 & 9 & 0.27 & 0.27 & 2.8 & 1 & 0 & 0.56 & 0.5 & 12.4 & -30.08 \\
\hline 09.2018 & 1 & 0.48 & 0.19 & 8.4 & 0.7 & 0.058 & 0.19 & 1 & 1.4 & -24.89 \\
\hline 09.2018 & 2 & - & 0.18 & 2.8 & 0.5 & 0.04 & 0.24 & - & 9.6 & -24.63 \\
\hline 09.2018 & 3 & 1.04 & 0.29 & 2.8 & 0.6 & 0.01 & 0.21 & 0.5 & 2.8 & -25.3 \\
\hline 09.2018 & 4 & 0.36 & 0.28 & 2.8 & 0.2 & 0.003 & 0.38 & 0.5 & 5.6 & -29.48 \\
\hline 09.2018 & 5 & 1.16 & 0.35 & 5.6 & 0.4 & 0 & 0.36 & 0.75 & 6.5 & -30.09 \\
\hline 09.2018 & 6 & 2.24 & 0.03 & 14 & 0.6 & 0.02 & 0.37 & 1 & 53.3 & -30.85 \\
\hline 09.2018 & 7 & 0.72 & 0.09 & 2.8 & 0.6 & 0.012 & 0.38 & 1 & 42.5 & -31.62 \\
\hline 09.2018 & 8 & 0.28 & 0.01 & 5.6 & 0.1 & 0.028 & 0.26 & 1 & 43.3 & -29.6 \\
\hline 09.2018 & 9 & 0.76 & 0.18 & 14 & 0.2 & 0.004 & 0.31 & 0.5 & 2.9 & -30.22 \\
\hline 10.2018 & 1 & 0.34 & 0.34 & 14 & 0.7 & 0.041 & 0.52 & 1 & - & -24.59 \\
\hline 10.2018 & 2 & 0.44 & 0.24 & 8.4 & 0.5 & 0.024 & 0.26 & - & - & -24.7 \\
\hline 10.2018 & 3 & 0.44 & 0.1 & 8.4 & 0.5 & 0.022 & 0.58 & 0.5 & 16.4 & -25.34 \\
\hline 10.2018 & 4 & 1 & 0.17 & - & 0.3 & 0.027 & 0.19 & 0.5 & 5.4 & -28.82 \\
\hline 10.2018 & 5 & 0.35 & 0.35 & 11.2 & 0.7 & 0.031 & 0.06 & 0.75 & 13.1 & -28.04 \\
\hline 10.2018 & 6 & 0.24 & 0.02 & 5.6 & 0.5 & 0.029 & 0.41 & 1 & 8 & -28.56 \\
\hline 10.2018 & 7 & 0.15 & 0.15 & 2.8 & 0.5 & 0.05 & 0.03 & 1 & 11.1 & -23.46 \\
\hline 10.2018 & 8 & 0.32 & 0.24 & 5.6 & 0.6 & 0.039 & 0.04 & 1 & 25 & -27.16 \\
\hline 10.2018 & 9 & 0.4 & 0.16 & 11.2 & 0.5 & 0.009 & 0.12 & 0.5 & 23.8 & -27 \\
\hline
\end{tabular}

Obtained results indicated that Służewiecki Stream and nearby reservoirs are significantly eutrophicated and the concentration of total phosphorus was a dominant factor. Reason of that state may be various, however, in general, the most important sources in surface waters in this area are municipal wastewater inflow and surface runoff, including agricultural land use (Wojtkowska and Bojanowski 2018). Nevertheless, the Służewiecki Stream is not recipient of any municipal wastewater and intensity of agriculture in this area is negligible, so the source of nutrients in stream remains unknown.
It should be noted that TSI was developed for assessment of trophic state in lakes, which are reservoirs of large area and slow water flow. However, bearing in mind that it is based on parameters which are possible to test in flowing waters as well as in standing waters and obtained results were comparable it is possible to indicate that utilization of TSI to evaluate trophic state of surface waters of Służewiecki Stream and nearby reservoirs was reasonable. 
Table 3 Obtained results of auxiliary parameters

\begin{tabular}{|c|c|c|c|c|c|c|c|c|}
\hline Date & ID & $\begin{array}{l}\mathrm{pH} \\
-\end{array}$ & $\begin{array}{l}\text { Cond } \\
\mu \mathrm{S} / \mathrm{cm}\end{array}$ & $\begin{array}{l}\text { Alkal } \\
\mathrm{mg} \mathrm{CaCO}_{3} / 1\end{array}$ & $\begin{array}{l}\mathrm{Ca} \\
\mathrm{mg} \mathrm{Ca} / \mathrm{l}\end{array}$ & $\begin{array}{l}\mathrm{Mg} \\
\mathrm{mg} \mathrm{Mg} / 1\end{array}$ & $\begin{array}{l}\mathrm{Cl}^{-} \\
\mathrm{mg} \mathrm{Cl} / 1\end{array}$ & $\begin{array}{l}\mathrm{SO}_{4}{ }^{2-} \\
\mathrm{mg} \mathrm{SO}_{4}{ }^{2-} / 1\end{array}$ \\
\hline 05.2018 & 1 & 7.61 & 1140 & 350 & 124.25 & 68.04 & 175 & 48 \\
\hline 05.2018 & 2 & 7.76 & 1137 & 350 & 116.23 & 19.44 & 170 & 44 \\
\hline 05.2018 & 3 & 7.71 & 913 & 250 & 66.53 & 24.3 & 155 & 58 \\
\hline 05.2018 & 4 & 7.67 & 1010 & 330 & 92.18 & 31.59 & 177 & 22 \\
\hline 05.2018 & 5 & 7.69 & 1064 & 325 & 85.77 & 44.71 & 187 & 28 \\
\hline 05.2018 & 6 & 7.71 & 901 & 200 & 68.94 & 26.73 & 165 & 40 \\
\hline 05.2018 & 7 & 7.64 & 920 & 195 & 68.14 & 29.16 & 163 & 60 \\
\hline 05.2018 & 8 & 7.64 & 989 & 200 & 64.13 & 31.59 & 205 & 50 \\
\hline 05.2018 & 9 & 7.49 & 801 & 245 & 56.11 & 55.89 & 100 & 80 \\
\hline 07.2018 & 1 & 8.04 & 1290 & 375 & 120.24 & 48.6 & 208 & 58 \\
\hline 07.2018 & 2 & 8.1 & 1305 & 360 & 102.6 & 41.31 & 211 & 70 \\
\hline 07.2018 & 3 & 7.9 & 1148 & 340 & 102.6 & 26.73 & 213 & 75 \\
\hline 07.2018 & 4 & 7.53 & 650 & 250 & 76.15 & 43.74 & 83 & 105 \\
\hline 07.2018 & 5 & 7.2 & 1152 & 275 & 120.24 & 51.03 & 173 & 0 \\
\hline 07.2018 & 6 & 8.01 & 614 & 190 & 40.08 & 24.3 & 128 & 55 \\
\hline 07.2018 & 7 & 7.77 & 633 & 250 & 72.14 & 26.73 & 128 & 63 \\
\hline 07.2018 & 8 & 7.65 & 836 & 200 & 64.13 & 36.45 & 168 & 58 \\
\hline 07.2018 & 9 & 7.45 & 740 & 225 & 104.21 & 36.45 & 78 & 85 \\
\hline 09.2018 & 1 & 7.66 & 1721 & 430 & 196.39 & 55.89 & 250 & 90 \\
\hline 09.2018 & 2 & 8.05 & 1405 & 475 & 72.14 & 38.88 & 230 & 55 \\
\hline 09.2018 & 3 & 8 & 1343 & 475 & 80.16 & 48.6 & 230 & 73 \\
\hline 09.2018 & 4 & 7.23 & 856 & 300 & 76.15 & 53.46 & 125 & 90 \\
\hline 09.2018 & 5 & 7.28 & 553 & 325 & 48.1 & 29.16 & 95 & 11 \\
\hline 09.2018 & 6 & 8 & 855 & 275 & 32.06 & 43.74 & 150 & 83 \\
\hline 09.2018 & 7 & 7.95 & 851 & 350 & 92.18 & 82.62 & 140 & 83 \\
\hline 09.2018 & 8 & 7.68 & 843 & 250 & 40.08 & 24.3 & 160 & 88 \\
\hline 09.2018 & 9 & 7.24 & 850 & 325 & 44.09 & 43.74 & 125 & 58 \\
\hline 10.2018 & 1 & 7.82 & 1358 & 390 & 76.95 & 54.43 & 190 & 75 \\
\hline 10.2018 & 2 & 8.01 & 1278 & 400 & 16.03 & 102.06 & 185 & 95 \\
\hline 10.2018 & 3 & 8.18 & 1094 & 300 & 24.05 & 68.04 & 165 & 65 \\
\hline 10.2018 & 4 & 7.58 & 736 & 195 & 44.09 & 46.17 & 107 & 98 \\
\hline 10.2018 & 5 & 7.79 & 612 & 180 & 32.06 & 38.88 & 110 & 7 \\
\hline 10.2018 & 6 & 7.76 & 779 & 190 & 32.06 & 54.43 & 135 & 65 \\
\hline 10.2018 & 7 & 7.81 & 778 & 200 & 20.04 & 55.89 & 135 & 75 \\
\hline 10.2018 & 8 & 8.1 & 803 & 175 & 25.65 & 51.03 & 140 & 58 \\
\hline 10.2018 & 9 & 7.85 & 706 & 250 & 33.67 & 65.12 & 102 & 100 \\
\hline
\end{tabular}

\section{Calculation of TLI for analysed subjects}

The range of values of TLI was between 5 and 8 (Table 5), and the highest values were observed in September and October. Average values of TLI were 6.4 in Służewiecki Stream, 6.5 in Bottom Berensewicz's Pond, 6.5 in Wyścigi Pond and 6.7 in Wilanowskie Lake. These results indicate that those subjects are in hypertrophic state (range 6.0-7.0). Trophic state in analysed reservoirs was determined mostly by phosphorus and nitrogen concentrations which were higher than reference limit values. High concentration of chlorophyll a and low transparency.
There were many studies aiming on establishing the acceptable criteria and classification levels of lakes basing on trophic state, nutrients, total phosphorus and other physical factors (transparency, dissolved oxygen) and biological (algae pigments) (OECD 1982; Vollenweider 1989; Galvez-Cloutier and Sánchez 2007; Zębek 2010; Ferreira et al. 2011). Conducted research allowed to identify quality significant quality parameters of waters of Służewiecki Stream and nearby reservoirs which have influence on trophic state and ecological state of this waters. Water quality in stream is bad. Main indicator of that state is concentration of total phosphorus and high concentration of TN. Calculated values 
Table 4 Obtained TSI values

\begin{tabular}{|c|c|c|c|c|c|c|c|c|c|c|c|c|}
\hline \multirow[t]{2}{*}{ ID } & \multicolumn{3}{|l|}{05.2018} & \multicolumn{3}{|l|}{07.2018} & \multicolumn{3}{|l|}{09.2018} & \multicolumn{3}{|l|}{10.2018} \\
\hline & TSI TP & TSI SD & TSI Chl & TSI TP & TSI SD & TSI Chl & TSI TP & TSI SD & TSI Chl & TSI TP & TSI SD & TSI Chl \\
\hline 1 & 70.6 & 60 & - & 91.9 & 60 & 31.6 & 93.2 & 60 & 33.9 & 57.3 & 60 & - \\
\hline 2 & 65.4 & - & - & 96.4 & - & 32.4 & 138 & - & 52.8 & 91.9 & - & - \\
\hline 3 & 65.4 & 65.8 & 37.4 & 57.3 & 50 & 35.8 & 104.3 & 50 & 40.8 & 91.9 & 50 & 58.1 \\
\hline 4 & 78.2 & 50 & 71.2 & 80.6 & 50 & 42.3 & 89 & 50 & 47.5 & 103.8 & 50 & 47.1 \\
\hline 5 & 71.9 & 55.9 & 51.1 & 89 & 55.9 & 46.7 & 105.9 & 55.9 & 48.9 & 87.3 & 55.9 & 55.9 \\
\hline 6 & 77.3 & 60 & 61.7 & 73.2 & 60 & - & 115.4 & 60 & 69.6 & 83.2 & 60 & 51.1 \\
\hline 7 & 76.4 & 60 & 67.7 & 57.3 & 60 & 56 & 99 & 60 & 67.4 & 73.2 & 60 & 54.2 \\
\hline 8 & 65.4 & 60 & 66.7 & 67.3 & 60 & 50.9 & 85.4 & 60 & 67.6 & 87.3 & 60 & 62.2 \\
\hline 9 & 83.8 & 50 & 65.7 & 67.3 & 50 & 55.3 & 99.8 & 50 & 41 & 90.5 & 50 & 61.7 \\
\hline
\end{tabular}

Table 5 Obtained TLI values

\begin{tabular}{lllll}
\hline ID & 05.2018 & 07.2018 & 09.2018 & 10.2018 \\
\hline 1 & 6.2 & 6 & 6.1 & 6.4 \\
2 & 6.7 & 6.3 & - & 8.1 \\
3 & 5.2 & 5.6 & 6.4 & 6.9 \\
4 & 6.8 & 5.9 & 6.2 & 7.1 \\
5 & 6.1 & 6.3 & 6.7 & 6.8 \\
6 & 6.4 & 6.5 & 7.8 & 6.2 \\
7 & 6.8 & 5.6 & 6.8 & 5.9 \\
8 & 5.9 & 5.6 & 6.7 & 6.6 \\
9 & 6.7 & 6 & 6.8 & 7.1 \\
\hline
\end{tabular}

of aggregated indexes of trophic state: TSI and TLI indicate eutrophic state of waters in Służewiecki Stream, Bottom Berensewicz's Pond, Wyścigi Pond and Wilanowskie Lake. It also indicates that it is rational to use those indexes to evaluate trophic state of flowing waters as well as standing waters. It should be noted that TLI index which is based on average values of each parameters is more restrictive than TSI which is based on one parameter (chlorophyll a, $\mathrm{TP}, \mathrm{SD})$. The reason may be reference scale proposed by its authors. TSI (TP) indicates high intensity of eutrophication, therefore TP may be the reason of that state in analysed subjects.

\section{Conclusions}

- The Służewiecki Stream is not a recipient of municipal wastewater, and agriculture in the catchment area is not intensive, and therefore, the cause of high concentrations of substances responsible for eutrophication is unknown. The cause may lie in illegal discharges of substances into the rainwater sewage system (despite the fact that the area is well canalized), recharge from bottom sediments or atmospheric deposition, including surface runoff from urbanized areas. Hypothesis on non-municipal origin of those pollutions is supported by high content of calcium, chlorides, sulphates the high alkalinity of stream's waters.

- Values of TSI and TLI indexes indicate high eutrophic state of analysed objects. The main factor responsible of that state is high TP concentrations.

- Evaluation of trophic state of waters utilizing TSI and TLI is suitable for the needs of water management. (Parparov et al. 2010) as it confirms the conclusion from common indicator. However, we do not found significant correlation between the values of trophic indicators (TN, TP, TLI, TSI) and $\delta^{13} \mathrm{POC}$.

- Actions aimed at restoring good quality of water in the Służewiecki Stream and nearby reservoirs would require the long-term identification of factors and pressures that could affect the condition of these waters, and then undertaking measures at limiting their impact on the Służewiecki Stream catchment area.

- Preventing an eutrophication should consist limitation of pressures related to nutrients to surface waters by utilizing the best available techniques and suitable legal procedures. Removing the effects of eutrophication results with the necessity of re-cultivation of reservoir and usually is time consuming and expensive.

Acknowledgements This research was co-financed by the Strategic Research Project of the Warsaw University of Technology "Circular Economy".

Authors' contributions Authors contributed equally to the publication.

Funding This research was co-financed by the Strategic Research Project of the Warsaw University of Technology "Circular Economy".

Availability of data and materials Samples were taken in 2018. Results of chemical analysis of samples are available. 


\section{Declarations}

Conflict of interest The authors declare that they have no conflict of interest.

Ethics approval The authors approved ethical responsibilities of journal.

Consent for publication The authors consent to the publication.

Open Access This article is licensed under a Creative Commons Attribution 4.0 International License, which permits use, sharing, adaptation, distribution and reproduction in any medium or format, as long as you give appropriate credit to the original author(s) and the source, provide a link to the Creative Commons licence, and indicate if changes were made. The images or other third party material in this article are included in the article's Creative Commons licence, unless indicated otherwise in a credit line to the material. If material is not included in the article's Creative Commons licence and your intended use is not permitted by statutory regulation or exceeds the permitted use, you will need to obtain permission directly from the copyright holder. To view a copy of this licence, visit http://creativecommons.org/licenses/by/4.0/.

\section{References}

Bartoszek L, Koszelnik P, Zamorska J, Gruca-Rokosz R, Zdeb M (2018) A preliminary study into the possibility of $\delta^{13} \mathrm{C}$ being used as a sensitive indicator of the trophic and hydrobiological status of aquatic ecosystems. J Ecol Eng 19:191-198. https://doi.org/10. $12911 / 22998993 / 89829$

Burns NM, Rutherford JC, Clayton JS (1999) A monitoring and classification system for New Zealand lakes and reservoirs. J Lake Res Manag 15(4):255-271. https://doi.org/10.1080/0743814990 9354122

Burns N, McIntosh J, Scholes P (2005) Strategies for managing the lakes of the Rotorua District. New Zealand Lake Reserv Manage 21(1):61-72

Carlson RE (1977) A trophic state index for lakes. Limnol Oceano 22:361-369

El-Serehy HA, Abdallah HS, Al-Misned FA, Al-Farraj SA, Al-Rasheid KA (2018) Assessing water quality and classifying trophic status for scientifically based managing the water resources of the Lake Timsah, the lake with salinity stratification along the Suez Canal. Saudi J Biol Sci 25(7):1247-1256. https://doi.org/10.1016/j.sjbs. 2018.05.022

Ferreira JG, Andersen JH, Borja A, Bricker SB, Camp J, Cardoso da Silva M, Garcés E, Heiskanen A, Humborg C, Ignatiades L, Lancelot C, Menesguen A, Tett P, Hoepffner N, Claussen U (2011) Overview of eutrophication indicators to assess environmental status within the European Marine Strategy Framework Directive.
Estua, Coas Shelf Sci 93(2):117-131. https://doi.org/10.1016/j. ecss.2011.03.014

Główny Urząd Geodezji i Kartografii (2021) Państwowy rejestr granic i powierzchni jednostek podziałów terytorialnych kraju. http:// www.gugik.gov.pl/. Accessed 24 April 2021.

Gu M, Schelske CL, Brenner M (2011) Relationship between sediment and plankton isotope ratios $\left(\delta^{13} \mathrm{C}\right.$ and $\left.\delta{ }^{15} \mathrm{~N}\right)$ and primary productivity in Florida lakes. Can J Fish Aquat Sci 53:875-883. https://doi.org/10.1139/f95-248

Galvez-Cloutier R, Sanchez M (2007) Trophic status evaluation for 154 Lakes in Quebec, Canada: Monitoring and Recommendations. Water Qual Res J Canada 42(4):252-268

Horton RK (1965) An index number system for rating water quality. J Water Pollu Cont Fed 37(3):300-305

Krajowy Zarząd Gospodarki Wodnej (2017) Baza danych przestrzennych aktualizacji planów gospodarowania wodami (aPGW). https://dane.gov.pl. Accessed 24 April 2021

Lehmann MF, Bernasconi SM, McKenzie JA, Barbieri A, Simona M, Veronesi M (2004) Seasonal variation of the $\delta^{13} C$ and $\delta^{15} \mathrm{~N}$ of particulate and dissolved carbon and nitrogen in Lake Lugano: Constraints on biogeochemical cycling in a eutrophic lake. Limn Oceano 49(2):15-429. https://doi.org/10.2307/3597852

Neverova-Dziopak E (2007) The ecological aspects of surface water protection. The Monograph. Publishing House of the Rzeszów Technical University, Rzeszów

Organization for Economic Cooperation and Development (1982) Eutrophication of waters. Monitoring, assessment and control, Paris, France

Parparov A, Gal G, Hamilton D, Kasprzak P, Ostapenia A (2010) Water quality assessment, trophic classification and water resources management. J Water Res Prot 2:907-915. https://doi.org/10. 4236/jwarp.2010.210108

State Register of Geographical Names (PRNG) (2018) Central Center for Geodetic and Cartographic Documentation (CODGiK). ID: 125035

Vollenweider RA (1989) Global problems of eutrophication and its control. In: Salaø̣ki J, Herodek S (eds) Conservation and management of lakes, vol 38. Symposium Biologica Hungarica, pp $19-41$

WIOŚ Warszawa (2017) Monitoring rzek w latach 2011-2016. https:// www.wios.warszawa.pl. Accessed 1 October 2018

WIOŚ Warszawa (2018) Monitoring rzek w 2017 r. https://www.wios. warszawa.pl. Accessed 1 October 2018

Wojtkowska M, Bojanowski D (2018) Influence of catchment use on the degree of river water pollution by forms of phosphorus. Ann Set Environ Prot 20:887-904

Wojtkowska M, Dmochowski D (2009) Seasonal character of changes in nitrogen forms in waters of Korytów and Łąki Korytowskie retention reservoirs. Environ Prot Eng 35(2):57-66

Zębek E (2010) Seasonal changes in net phytoplankton in two lakes with differing morphometry and trophic status (northeast Poland). Fish Aqu Life 17:267-278 